\title{
Reduction of Radiation Dose according to Geometric Parameters from Digital Coronary Angiography
}

\author{
Yeonghan Kang, PyongKon Cho* \\ Department of Radiology, Daegu Catholic University Hospital, \\ Department. of Radiological Science, Catholic University of Daegu* ${ }^{*}$

\section{디지털 심혈관조영장치의 기하학적 특성에 따른 선량 감소} \\ 강영한, 조평곤* \\ 대구가톨릭대학교병원 영상의학과, 대구가톨릭대학교 방사선학과*
}

\begin{abstract}
This study aims to find out geometric parameters which practitioner adjustable to reduce dose in coronary angiography. We take fluoroscopy and cine exposure by use of phantom, and got dose use the dose-area product(DAP) meter of angiography device, than convert DAP to effective dose. As results, Cine exposure shows higher dose measurement about 6-7 times than fluoroscopy. Dose in frame per second(FPS) mode could be decrease down to $70 \%$, as lower FPS. In view of X-ray tube angle, LAO $45^{\circ}+$ Caudal $30^{\circ}$ shows highest dose measurement. More use of Collimator, lower dose measurement. Source-image intensifier distance(SID) get longer to $10 \mathrm{~cm}$, dose of each fluoroscopy and cine exposure increase up to 25-30\%. Image magnification of field of view(FOV) could increase dose up to 1.21-2 times. Also table-image intensifier distance get longer to $10 \mathrm{~cm}$, dose increased 1.11-1.25 times. Practitioner can adjust several geometric parameters, as FPS mode, tube angle, Collimation, SID, table-image intensifier distance, FOV. And each factors can reduce radiation dose in coronary angiography.
\end{abstract}

Key Words : Digital coronary angiography, Fluoroscopy, Cine exposure, Dose reduction

\section{요 야}

심혈관 촬영 시 선량감소를 위해 실무자가 조절 가능한 기하학적 특성을 살펴보고, 각 특성에 따른 유효선량을 비교 해 보았다. 인체 모형 팬텀을 이용하여 투시촬영과 영화촬영을 시행하였고, 선량의 측정은 심혈관 장치의 DAP meter 를 이용하여 DAP 값을 유효선량으로 환산하였다. 먼저 영화촬영은 투시촬영에 비해 기하학적 특성 전반에 걸쳐서 선 량이 약 6-7배 높았다. FPS mode에 따른 선량은 FPS를 낮게 설정할수록 선량이 70\%까지 감소하였다. 선관 각도에 따른 선량은 $\mathrm{LAO} 45^{\circ}+\mathrm{Caudal} 30^{\circ}$ 이 가장 높게 측정되었고, 조사야 조절장치를 많이 적용할수록 선량은 감소하였다. $\mathrm{X}$-선관과 영상증배관의 거리가 $10 \mathrm{~cm}$ 멀어질수록 투시촬영과 영화촬영에서 각각 선량이 25-35\%까지 증가하였다. $\mathrm{FOV}$ 가 확대될수록 선량이 1.21-2배 증가하였고, 테이블과 영상증배관 거리가 $10 \mathrm{~cm}$ 멀어질수록 선량은 $1.11-1.25$ 배 까지 증가하였다. 따라서 본 연구에서 실험한 기하학적 특성인 FPS mode, 선관 각도, 조준기, 선관과 영상증배관 거 리, 테이블과과 영상증배관 거리, $\mathrm{FOV}$ 영상 확대 등은 중재적 시술 시 실무자가 수시로 조절 가능한 인자이며, 각 특 
성에 따라 선량 감소 효과를 기대할 수 있다.

중심단어: 디지털심혈관조영장치, 영화촬영, 투시촬영, 선량 감소

\section{I. 서 론}

최근 방사선 의료에서 심장혈관의 중재적 시술이 전문화되어가고, 적용범위도 계속 확대되어 그 증가율 이 연 $10-20 \%$ 를 보이고 있다[1]. 이는 연속적이고 장시 간에 걸쳐 방사선에 노출되는 시술이 증가되는 것을 말하며, X선 사용의 확장은 피폭선량을 증가시켜 방사 선 장해의 증가를 수반하게 된다 ${ }^{[2]}$. 특히 심혈관검사 는 긴 투시시간 및 많은 연속촬영을 하며 진단과 치료 가 이루어지기 때문에 높은 선량을 받게 된다 ${ }^{[3]}$. Wall 등은 심혈관 검사 시 유효선량이 4.6-15.8 mSv 이고, 심 혈관성형술(Angioplasty)까지 시행하면 유효선량이 7.5-57.0 mSv 까지 될 수도 있다고 하여, 검사 중 피폭 선량이 상당함을 경고하고 있다 ${ }^{[4]}$. 또한 방사선 종사 자 근무분야별 피폭도 심혈관검사실에서 가장 많은 것으로 보고하였다 ${ }^{[5,6]}$. 이와 관련해서 ICRP와 IAEA, 식약청 등의 방사선 안전 전문기관에서는 심혈관검사 시 발생하는 피폭선량을 최소화하기 위한 방법 중 촬 영 시간을 줄이는 것 외에 몇 가지 방안을 제시하였다 [7-9]. 그 내용은 심장혈관 중재적 시술 시 획득 영상 수 를 제한하고, 불필요한 영상 확대 지향, 투시시간과 선 량률 제한, $\mathrm{X}$-선관의 필터를 증가시키며, 저격영상 (spot image) 대신 영상캡처(image capture)를 이용하고, 펄스 투시촬영(pulsed fluoroscopy)의 사용, 관전압 증가 등의 내용이었다. 실제로 이러한 방법들은 선량감소에 효과적이며 간단한 절차적, 기기적 수단들이 임상목적 을 저해하지 않고 환자선량을 줄일 수 있으며, 모든 의료진 선량도 상당히 줄이는 것으로 나타났다 ${ }^{[10]}$. 하 지만 이러한 선량 경감을 위한 방법이 중재적 시술과 정에 항상 적용할 수 있는 방법이 아니라 시술상황에 따라 가변적일 수 있고, 실무자들이 상황에 따라 적절 히 선량경감 조치를 취하지 못하는 경우도 발생한다. 또한 실무자들이 조절 가능한 요인들에 대해 명확히 알지 못하거나 쉽게 간과하는 상황도 있을 수 있다. 적절치 않은 방사선 장비나 피폭선량을 무시한 투시 촬영이 지속된다면 의료진의 노출량이 상당히 증가할 수 있고, 시술자 뿐 아니라 시술실 안에 같이 있는 다
른 의료진도 방사선의 피폭을 피할 수 없다. 따라서 시술자와 방사선사는 심혈관 검사 및 시술에 있어서 방사선 선량에 대해 깊은 관심을 가져야 하며 장비의 적절한 선량 감소 방법을 적용하여 검사하여야 한다.

본 연구의 목적은 심혈관 검사 시 투시촬영으로 인 하여 발생하는 방사선의 선량 감소를 위해 실제로 조 절 가능한 기하학적 특성들이 어떤 것이 있는지 알아 보고, 기하학적 특성에 따른 선량 감소효과를 확인하 여서 환자 및 시술자의 피폭선량을 기술적으로 감소 시킬 수 있는 방안을 제시하고자 하였다.

\section{II. 연구 방법}

\section{1. 실험장비 및 설계}

본 실험에 이용한 디지털 혈관 영화장치는 3 차원 디지털영상 혈관조영촬영장치(Allura Xper, FD 10 Philips, Netherland)이었고, 기하학적 특성에 따라 각각 투시촬영(fluoroscopy)과 영화촬영(Cine exposure)을 시 행하였다. X-선관(tube)과 영상증배관(image intensifier, I.I)과의 거리는 기본적으로 $100 \mathrm{~cm}$ 이었고, 영상증배 관의 선장 크기(beam field size)는 원형의 $25 \mathrm{~cm}^{2}$ 이었다. 관전압, 관전류, 조사 시간 등의 방사선 조사조건은 자 동노출조절장치(automatic exposure control, $\mathrm{AEC}$ )를 이 용하였고, 관전압 범위는 70 120 kV 이었다. 여과장치 (filtration)는 기본적으로 $1.5 \mathrm{mmAl}$ 과 $0.2 \mathrm{mmCu}$ 가 장착이 되었고, 선택적 투시용 여과(selective fluoro prefilter) 시 $0.1 \mathrm{mmCu}+1.0 \mathrm{mmAl}$ 과 $0.9 \mathrm{mmCu}+1.0 \mathrm{mmAl}$ 이 적용 되었다. 선택용 투시여과는 시간당 프레임 수(frame per second, $\mathrm{FPS}$ )에 따라 다르며 표 1과 같다. 촬영은 두께가 $18 \mathrm{~cm}$ 인 인체 모형 팬텀(anthropomorphic phantom model, KYOTO KAGAKU, PBU-60, JAPAN)을 촬영대 위에 놓고, 기하학적 특성을 조절하며 촬영하였으며, 각각 3 회 촬영하여 평균을 구하였다. 
Table 1. Selective Prefilter of FPS mode

\begin{tabular}{ccc}
\hline FPS mode & Fluoroscopy & Exposure \\
\hline Coronary 15 & $1.0 \mathrm{mmAl}+0.1 \mathrm{mmCu}$ & Non-filter \\
Cardiac EP 15 & $1.0 \mathrm{mmAl}+0.9 \mathrm{mmCu}$ & $1.0 \mathrm{mmAl}+0.1 \mathrm{mmCu}$ \\
Cardiac EP 7.5 & $1.0 \mathrm{mmAl}+0.9 \mathrm{mmCu}$ & $1.0 \mathrm{mmAl}+0.1 \mathrm{mmCu}$ \\
Cardiac EP 3.75 & $1.0 \mathrm{mmAl}+0.9 \mathrm{mmCu}$ & $1.0 \mathrm{mmAl}+0.1 \mathrm{mmCu}$ \\
\hline
\end{tabular}

\section{2. 선량의 측정}

선량측정은 장비에 장착되어 있는 면적선량계(dose area product meter)를 통해 모니터에 제시되는 면적-선 량 곱(dose area product, DAP) 값과 공기 커마(air kerma, $\mathrm{AK})$ 를 이용하였다. DAP와 $\mathrm{AK}$ 는 선관의 조준 기(collimator) 위쪽 부분(tube housing)에 내장되어 있는 DAP meter(DIAMENTOR M4-KDK, PTW, Freiburg, Germany)에 의해 측정된다. DAP meter의 정도관리는 전자계(Radcal 9010 electrometer)와 이온챔버(90X5-6 ionization chamber)를 이용하여 관리업체에서 주기적으 로 시행하였고, DAP meter의 에너지 의존성은 관전압 범위의 $10 \%$ 를 넘지 않았다. DAP 값은 유효선량으로 전환할 수 있는데, 본 연구에서는 DAP 값에 유효선량 전환계수 $0.20 \mathrm{mSv} / \mathrm{Gy} \cdot \mathrm{cm}^{2}$ 를 곱하여 계산하였다 ${ }^{[11,12]}$.

$\mathrm{E}(\mathrm{mSv})=\operatorname{DAP}\left(\mathrm{Gy} \cdot \mathrm{cm}^{2}\right) \times \mathrm{CCdap}\left(\mathrm{mSv} / \mathrm{Gy} \cdot \mathrm{cm}^{2}\right)$

CCdap : 유효선량 전환계수 $\left(0.2 \mathrm{mSv} / \mathrm{Gy} \cdot \mathrm{cm}^{2}\right)$

\section{3. 기하학적 특성 실험}

1) 시간당 프레임 수(frame per second, FPS mode) 설정

장치의 FPS mode 종류는 Coronary 15, Cardiac EP 15, Cardiac EP 7.5, Cardiac EP 3.75 등이 있으며, 각각 의 FPS mode에 따라 아래 선관(Under tube) 방식으로 선관-영상증배관 거리(source-image intensifier distance, $\mathrm{SID})$ 를 $100 \mathrm{~cm}$ 으로 설정하여 팬텀에 수직 입사하였다. Cardiac 15는 초당 15프레임 촬영을 뜻하며, 촬영은 투 시촬영(fluoroscopy)과 영화촬영(Cine exposure)로 구분 하여 각각 10 초 동안 촬영하여 선량을 비교하였다.

\section{2) X-선관 각도(tube angulation) 변화}

먼저 FPS는 Cardiac EP 15 mode를 기본으로 설정하 였고, 팬텀을 테이블에 올려놓고 촬영을 하였다. 촬영 각도는 Under tube 수직입사(AP view), $\mathrm{LAO} 45^{\circ}+$ Caudal $30^{\circ}$, $\mathrm{LAO} 45^{\circ}+$ Cranial $30^{\circ}$, RAO $30^{\circ}+$ Cranial $30^{\circ}$, RAO $30^{\circ}+$ Caudal $30^{\circ}$ 로 5 가지 방향을 설정 하였다(Fig. 1). 각 각의 위치에서 10 초간 투시촬영과 영화촬영을 시행하 였다.

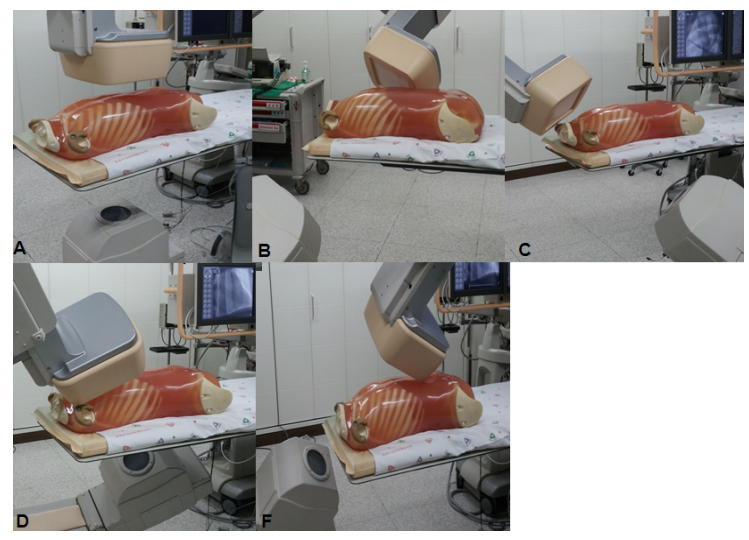

Fig 1. Set up of view position for tube angulation A : AP view, B : LAO $45^{\circ}+$ Caudal $30^{\circ}$, C : LAO $45^{\circ}+$ Cranial $30^{\circ}$, D : RAO $30^{\circ}+$ Cranial $30^{\circ}$, E : RAO $30^{\circ}+$ Caudal $30^{\circ}$

\section{3) 조사야 조절장치(Collimation) 조절}

영상의 조사야 조절을 위해 조정기의 조사야 스틱 (collimator stick)을 이용하여 조절하였으며, 조사야는 모니터의 조사야 크기를 이용하여 가로X세로로 측정 하였다. 팬텀을 테이블 중앙에 위치하여 Under tube 방 향으로 수직 촬영 하였고, 조사야 크기는 $28 \times 28 \mathrm{~cm}$ 에 서 $11 \times 11 \mathrm{~cm}$ 까지 줄여가며 5초간 촬영하였다(Fig. 2).

\section{4) 투시시야(field of view, FOV) 조절}

$\mathrm{FOV}$ 는 조정기의 FOV 확대 기능을 이용하여 25", $20 ", 15$ ”로 변화하며 투시 촬영 및 영화 촬영을 각각 5 초씩 시행하였다. 인체팬텀을 테이블 중앙에 위치하 여 Under tube 방향으로 수직 촬영 하였다(Fig. 3). 
5) X-선관-영상증배관 거리 (source- image intensifier distance, SID)

인체팬텀을 테이블 중앙에 위치하여 Under tube 방 향으로 수직 촬영 하였고, 영상증배관의 거리를 $90 \mathrm{~cm}$ $\sim 120 \mathrm{~cm}$ 까지 $10 \mathrm{~cm}$ 단위로 조절하며 촬영하였다. 각 각의 거리에서 투시촬영 및 영화촬영을 5 초간 시행하 며 선량을 측정하였다(Fig. 4-A).

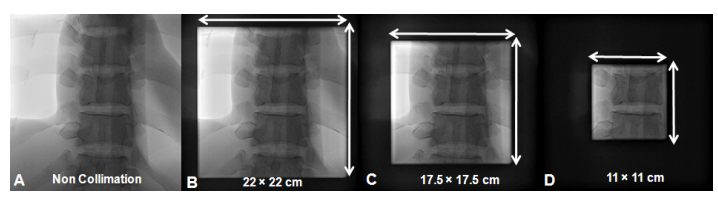

Fig 2. Set up for collimation $(22 \times 22 \mathrm{~cm}, 17.5 \times 17.5 \mathrm{~cm}, 11 \times 11 \mathrm{~cm})$

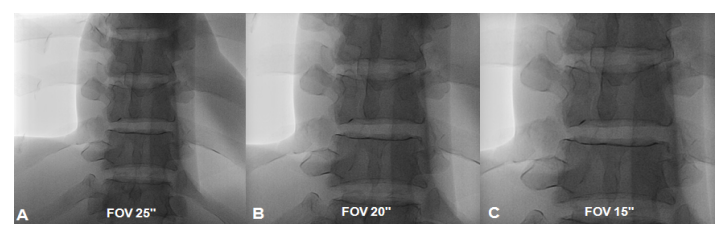

Fig 3. Set up for Field of view(25, 20, 15 inch)

6) 테이블과 영상증배관 거리 (Table-image intensifier distance)

$\mathrm{SID}$ 는 $100 \mathrm{~cm}$ 으로 고정한 채 영상증배관과 테이블 거리가 $30 \mathrm{~cm}$ 되는 지점(isocenter)을 기준으로 정하였 다. 테이블을 선관방향으로 이동하여 isocenter에서 10, $20,30 \mathrm{~cm}$ 떨어진 지점(테이블-영상증배관 거리는 40 , $50,60 \mathrm{~cm}$ )에서 투시촬영 및 영화촬영을 각각 5 초간 시 행 하였다(Fig. 4-B).

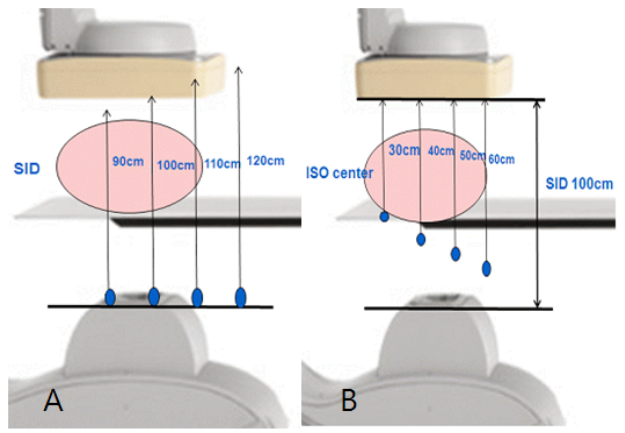

Fig 4. A : Set up for source-image intensifier distance $(90,100,110,120 \mathrm{~cm}), \mathrm{B}$ : Set up for table-image intensifier distance $(30,40,50,60 \mathrm{~cm})$

\section{III. 결 과}

\section{FPS mode에 따른 선량}

Cardiac EP 15 mode에서의 유효선량을 1.00 기준으 로 하였을 때, Fluoroscopy에서 Cardiac 7.5 mode에서의 유효선량은 0.91, Cardiac EP 3.75 mode에서는 0.82이었 다. Cine Exposure에서도 시간 당 프레임 수가 적을수 록 유효선량은 $\quad 50-80 \%$ 까지 감소하였다(Table 2). Fluorocopy mode와 Exposure mode에 따른 유효선량은 Cardiac EP 15 mode에서 Exposure mode가 약 15배 높 았다.

\section{2. $\mathrm{X}$-선관 각도에 따른 선량}

$\mathrm{X}$-선관 각도에 따른 선량은 Direct $\mathrm{AP}$ 방향에서의 유효선량을 1.00 기준으로 하였을 때, $\mathrm{LAO} 45^{\circ}+$ Caudal $30^{\circ}$ 에서 Fluoro mode의 유효선량은 1.05, Exposure mode는 1.08 이었고, RAO $30^{\circ}+$ Cranial 30 view의 Fluoro mode는 0.38 , Exposure mode는 0.42로 유효선량이 가장 낮았다(Table 3). 
"Journal of the Korean Society of Radiology, Volume 7, Number 4"

Table 2. Comparison of effective dose according to FPS mode

\begin{tabular}{ccccccccc}
\hline \multirow{2}{*}{ fps mode } & \multicolumn{3}{c}{ Fluoroscopy } & \multicolumn{3}{c}{ Cine Exposure } \\
\cline { 2 - 8 } & AK(mGy) & DAP(mGycm2) & Effective dose(mSv) & odds & AK(mGy) & DAP(mGycm2) & Effective dose(mSv) & odds \\
\hline Coronary 15 & 2.50 & 458 & 0.092 & 4.38 & 22.20 & 2977 & 0.595 & 1.89 \\
Cardiac EP 15 & 0.86 & 105 & 0.021 & 1.00 & 11.77 & 1571 & 0.314 & 1.00 \\
Cardiac EP 7.5 & 0.65 & 95 & 0.019 & 0.90 & 5.88 & 786 & 0.157 & 0.50 \\
Cardiac EP 3.75 & 0.59 & 86 & 0.017 & 0.81 & 2.35 & 315 & 0.063 & 0.20 \\
\hline
\end{tabular}

Table 3. Comparison of effective dose according to tube angulation

\begin{tabular}{ccccccccc}
\hline \multirow{2}{*}{ view } & \multicolumn{3}{c}{ Fluoroscopy } & \multicolumn{4}{c}{ Cine Exposure } \\
\cline { 2 - 8 } & AK(mGy) & DAP(mGycm2) & Effective dose(mSv) & odds & AK(mGy) & DAP(mGycm2) & Effective dose(mSv) & odds \\
\hline Direct AP & 0.86 & 105 & 0.021 & 1.00 & 11.77 & 1457 & 0.291 & 1.00 \\
LAO $45^{\circ}+$ Caudal $30^{\circ}$ & 1.02 & 111 & 0.022 & 1.05 & 14.39 & 1571 & 0.314 & 1.08 \\
LAO $45^{\circ}+$ Cranial $30^{\circ}$ & 0.61 & 77 & 0.015 & 0.71 & 9.84 & 1014 & 0.203 & 0.70 \\
RAO $30^{\circ}+$ Cranial $30^{\circ}$ & 0.31 & 42 & 0.008 & 0.38 & 4.99 & 616 & 0.123 & 0.42 \\
RAO $30^{\circ}+$ Caudal $30^{\circ}$ & 0.50 & 72 & 0.014 & 0.67 & 7.87 & 1034 & 0.207 & 0.71 \\
\hline
\end{tabular}

Table 4. Comparison of effective dose according to Collimation

\begin{tabular}{ccccccccc}
\hline \multirow{2}{*}{ Collimation(cm) } & \multicolumn{4}{c}{ Fluoroscopy } & \multicolumn{4}{c}{ Cine Exposure } \\
\cline { 2 - 8 } & AK(mGy) & DAP(mGycm2) & Effective dose(mSv) & odds & AK(mGy) & DAP(mGycm2) & Effective dose(mSv) & odds \\
\hline Non collimation & 1.38 & 157 & 0.031 & 1.00 & 8.74 & 977 & 0.195 & 1.00 \\
$22 \times 22$ & 1.29 & 101 & 0.020 & 0.65 & 8.24 & 626 & 0.125 & 0.64 \\
$17.5 \times 17.5$ & 1.22 & 72 & 0.014 & 0.45 & 7.78 & 449 & 0.090 & 0.46 \\
$11 \times 11$ & 1.13 & 30 & 0.006 & 0.19 & 7.36 & 195 & 0.039 & 0.20 \\
\hline
\end{tabular}

\section{3. 조사야 조절장치 설정에 따른 선량}

조사야 조절장치를 전혀 사용하지 않는 상태의 유 효선량을 기준 1.00 으로 하면, 조준기 설정을 $22 \times 22$, $17.5 \times 17.5,11 \times 11$ 로 할수록 Fluoroscopy mode에서 선량은 $0.65,0.45,0.19$ 배까지 감소하였다. Exposure mode에서 도 조사야 조절장치를 $22 \times 22,17.5 \times 17.5,11 \times 11$ 로 증가 할수록 선량은 0.64. 0.46, 0.20배로 감소하였다(Table 4).

\section{X-선관과 영상증배관 거리 변화에 따른 선량}

$\mathrm{X}$-선관과 영상증배관의 거리에 따른 선량은 $\mathrm{SID}$ $100 \mathrm{~cm}$ 를 1.00 기준으로 하면, SID가 $90 \mathrm{~cm}$ 에서 Fluoro mode 유효선량은 0.61로 감소하였고, Exposure mode에 서는 0.80 으로 감소하였다. $\operatorname{SID}$ 가 $110 \mathrm{~cm}, 120 \mathrm{~cm}$ 으로 멀어질수록 유효선량은 Fluoro mode에서 1.16, 1.23배 로 증가하였다. SID가 $10 \mathrm{~cm}$ 멀어질수록 Fluoroscopy mode와 Exposure mode 각각 선량이 $15-25 \%$ 증가하였 다(Table 5).

\section{5. 투시시야(FOV) 변화에 따른 선량}

FOV 25"에서의 유효선량을 1.00 기준으로 하면, FOV가 20", 15"로 확대하게 되면 Fluoroscopy mode에 서 선량은 큰 차이가 없었고, Exposure mode에서도 마 찬가지였다. 진단방사선 영역에서 흡수선량에 해당하 는 $\mathrm{AK}$ 는 1.23 에서 2.21로 증가하였고, Exposure mode 에서도 $\mathrm{AK}$ 는 FOV 25"보다 FOV 15"에서 선량이 2배 정도 되었다(Table 6). 이는 $\mathrm{SID}$ 의 변화 없이 FOV만 변한다면 $\mathrm{DAP}$ 는 일정한 값을 나타내고, $\mathrm{AK}$ 는 $\mathrm{FOV}$ 가 확대될수록 선량도 증가한다는 것을 알 수 있다. 
"Reduction of Radiation Dose according to Geometric Parameters from Digital Coronary Angiography"

Table 5. Comparison of effective dose according to source-image intensifier distance(SID)

\begin{tabular}{ccccccccc}
\hline \multirow{2}{*}{ SID(cm) } & \multicolumn{4}{c}{ Fluoroscopy } & \multicolumn{5}{c}{ Cine Exposure } \\
\cline { 2 - 8 } & AK(mGy) & DAP(mGycm2) & Effective dose(mSv) & odds & AK(mGy) & DAP(mGycm2) & Effective dose(mSv) & odds \\
\hline 90 & 0.58 & 94 & 0.019 & 0.61 & 5.45 & 843 & 0.169 & 0.80 \\
100 & 1.10 & 156 & 0.031 & 1.00 & 7.81 & 1055 & 0.211 & 1.00 \\
110 & 1.48 & 181 & 0.036 & 1.16 & 9.77 & 1127 & 0.225 & 1.07 \\
120 & 1.80 & 190 & 0.038 & 1.23 & 11.47 & 1149 & 0.230 & 1.09 \\
\hline
\end{tabular}

Table 6. Comparison of effective dose according to field of view(FOV)

\begin{tabular}{ccccccccc}
\hline \multirow{2}{*}{ FOV } & \multicolumn{4}{c}{ Fluoroscopy } & \multicolumn{4}{c}{ Cine Exposure } \\
\cline { 2 - 8 } & AK(mGy) & DAP(mGycm2) & Effective dose(mSv) & odds & AK(mGy) & DAP(mGycm2) & Effective dose(mSv) & odds \\
\hline $25^{\prime \prime}$ & 1.23 & 169 & 0.034 & 1.00 & 7.07 & 929 & 0.186 & 1.00 \\
$20 "$ & 1.56 & 171 & 0.034 & 1.00 & 10.6 & 934 & 0.187 & 1.01 \\
$15^{\prime \prime}$ & 2.21 & 166 & 0.033 & 0.97 & 13.53 & 940 & 0.189 & 1.02 \\
\hline
\end{tabular}

Table 7. Comparison of effective dose according to Table-image intensifier distance

\begin{tabular}{ccccccccc}
\hline \multirow{2}{*}{$\begin{array}{c}\text { Table-detector } \\
\text { distance(cm) }\end{array}$} & \multicolumn{4}{c}{ Fluoroscopy } \\
\cline { 2 - 8 } & AK(mGy) & DAP(mGycm2) & Effective dose(mSv) & odds & AK(mGy) & DAP(mGycm2) & Effective dose(mSv) & odds \\
\hline 30 & 1.17 & 178 & 0.036 & 1.00 & 7.02 & 1012 & 0.202 & 1.00 \\
40 & 1.25 & 185 & 0.037 & 1.03 & 7.88 & 1147 & 0.229 & 1.13 \\
50 & 1.47 & 199 & 0.040 & 1.11 & 9.63 & 1229 & 0.246 & 1.22 \\
60 & 1.70 & 212 & 0.042 & 1.17 & 11.32 & 1263 & 0.253 & 1.25 \\
\hline
\end{tabular}

\section{6. 테이블과 영상증배관 거리에 따른 선량}

테이블에서 영상증배관의 거리 $30 \mathrm{~cm}$ 을 1.00 기준 으로 하였을 때 $40,50,60 \mathrm{~cm}$ 으로 거리가 멀어질수록 투시 mode는 1.03, 1.11, 1.17로 증가하였다. Exposure mode에서도 선량은 각각 $1.13,1.22,1.25$ 배로 증가하였 다(Table 7).

\section{$\mathrm{IV}$. 고 찰}

$\mathrm{DAP}$ 는 $\mathrm{X}$-선 빔이 조사되는 영역에 직접적으로 장 착이 된 편평이온챔버(flat ionization chamber)로 측정된 다. 편평 챔버는 $\mathrm{X}$-선이 거의 다 투과될 수 있고, 이 챔버의 중심 $1.7 \times 1.7 \mathrm{~cm}$ 의 영역에서 두 번째 챔버가 있어서 $\mathrm{AK}$ 를 측정할 수 있도록 설계되어 사용되고 있 다 ${ }^{[13]}$. DAP는 선량을 직접 측정하는 것은 아니고 선추 의 단면적과 $\mathrm{AK}$ 를 나타내는 것으로써 후방산란계수 및 $\mathrm{X}$-선관 $\mathrm{kVp}$ 의 변화를 종합하여 선량으로 표시한다.
$\mathrm{DAP}$ 는 방사선 조사 방향이 지속적으로 변하고, 불규 칙적인 혈관조영 검사에서는 유효선량을 평가하는데 표면입사선량보다 신뢰성이 높다 ${ }^{[14]}$.

기하학적 특성 중 FPS는 초당 몇 장의 정지영상(still image)을 보여주느나는 의미인데, 여러 장의 정지 영상 이 연속적으로 보임으로써 하나의 연결된 영상으로 보여 진다. 따라서 프레임 수가 많을수록 영상이 자연 스럽다. 심혈관 장치에서 시간 당 30 frame에서 15 frame로 frame 수가 줄어들게 되면, 선량은 $50 \%$ 감소 효과를 기대할 수 있지만 관전류가 증가하기 때문에 실제 선량 감소는 $25 \%-28 \%$ 정도가 되고, 프레임 수가 초당 10 frame, 7.5 frame으로 감소하게 되면 선량 감소 는 $38 \%, 49 \%$ 로 감소하게 된다 ${ }^{[15]}$. 본 연구에서 이용된 심혈관장치는 15 frame부터 7.5 frame, 3.75 frame으로 FPS가 줄어들수록 선량은 투시촬영 에서 $10 \%, 18 \%$ 로 감소하였고, 영화촬영에서는 $50 \%, 80 \%$ 까지 감소하였 다. 따라서 최소 프레임인 3.75 mode를 적극적으로 이 용하는 것이 선량 감소효과에 도움이 된다. 시간 당 
프레임 수가 적어지면 화질이 다소 떨어질 수 있으나 육안적 판단은 시술과정에 지장을 주는 정도는 아니 었다. 하지만 미세한 부위를 보고자 할 때는 화질이 떨어질 수 있으므로 진단과 시술에 지장을 주지 않는 한 최소의 프레임 설정이 요구된다 ${ }^{[8]}$.

심장의 위치는 가슴 중앙에서 약간 왼쪽으로 치우 쳐 양쪽 폐 사이에 위치한다. 이런 해부학적 구조 때 문에 X-선관과 환자피부와의 거리는 $\mathrm{RAO}$ (right anterior oblique) view 보다 LAO(left anterior oblique) view에서 더 짧다. 이는 동일한 시간으로 투시조영을 한다면 $\mathrm{LAO}$ view에서 더 많은 양의 방사선이 피부에 조사된 다는 의미이다. 또한 우측 관상동맥 중재시술 시에는 좌측 관상동맥보다 더 높은 $\mathrm{DAP}$ 수준이 필요한 것으 로 나타났고, 서로 다른 $\mathrm{X}$-선관의 각도에 따라 환자에 대한 방사선 조사에도 상당한 영향을 받는다 ${ }^{[9]}$. 본 연 구에서 $\mathrm{LAO} 45^{\circ}+\mathrm{Caudal} 30^{\circ}$ view에서 유효선량이 수 직 촬영보다 5-8\% 높았고, $\mathrm{RAO} 30^{\circ}+\mathrm{Cranial} 30$ view에 서는 $60 \%$ 가량 낮게 나타난 이유도 동일한 맥락인 것 으로 판단된다.

투시촬영 시 조준기를 이용하여 필요부위에만 $\mathrm{X}$-선 을 조사하게 되면 피폭부위의 크기 감소 뿐 만 아니라 산란선의 감소로 인해 입사선량을 줄일 수 있고 영상 의 화질도 개선할 수 있다 ${ }^{[8]}$. 조사야 조절장치를 조절 하여 조사야를 $30 \%, 50 \%$ 축소하였을 때 선량 감소 효 과는 각각 $15 \%, 46 \%$ 의 선량감소 효과가 있었다 ${ }^{[16]}$. 본 연구에서 조사야 조절장치를 $22 \%, 38 \%, 60 \%$ 축소 시 선량감소효과는 $35 \%, 55 \%, 80 \%$ 로 이전의 연구보다 더 큰 것으로 나타났다. 조사야를 줄이게 되면 X-선 관전 류와 펄스 폭(pulse width)도 함께 증가하게 된다. 그래 서 조사야를 증가하게 되면 $\mathrm{DAP}$ 값도 감소하게 되는 것이지만 조사야를 줄인다고 해서 $\mathrm{DAP}$ 가 비례적으로 감소하게 되는 것은 아니다 ${ }^{[2]}$.

투시촬영 시 선량감소를 위해 조절 가능한 기하학 적 특성 중 $\mathrm{X}$-선관과 영상증배관과의 거리, 환자와 영 상증배관 거리가 중요한 부분을 차지한다. 혈관조영장 치 대부분은 $\mathrm{X}$-선관의 위치와 영상증배관과 별도로 움직이게 되어, 그 사이의 거리가 고정되어 있지 않다. 따라서 선관과 환자가 가까워지거나 환자와 영상증배 관이 더 멀어지게 되면 영상은 확대되고, 영상의 흐려 짐(blur) 현상이 증가한다. 선량을 감소하려면 환자와
선관 간격을 최대한 멀게 하여 입사면의 방사선 세기 를 최대한 줄이고, 환자와 영상증배관의 간격은 최대 한 가까이 한다. 환자와 선관의 거리가 반으로 줄 때 마다 입사선량의 강도는 4 배씩 증가하고, 영상증배관 과 환자의 거리가 반으로 줄 때마다 같은 영상화질을 구현하기 위한 입사선량의 강도는 반으로 감소한다 [8,16]. 환자와 영상증배관의 거리 $20 \mathrm{~cm}$ 에서 $40 \mathrm{~cm}, 60$ $\mathrm{cm}$ 으로 멀어질수록 피부선량은 1.8 배, 4.0 배 늘어난다 [15]. 본 연구에서도 선관과 영상증배관의 거리가 $10 \mathrm{~cm}$ 멀어질수록 선량은 $15-25 \%$ 증가하였고, 영상증배관과 테이블의 거리가 $10 \mathrm{~cm}$ 떨어질수록 선량은 $10-17 \%$ 까지 증가하였다. 따라서 투시촬영 시마다 가변적인 거리를 실시간으로 조절하여 환자와 $\mathrm{X}$-선관 간격은 최대한 멀게 하고, 환자와 영상증배관 간의 간격은 최대한 가 까이 하는 것이 실무자에게 항상 요구된다.

영상의 확대를 위한 FOV는 좁은 FOV로 변화하면 영상증배관에서 필요로 하는 선량도 증가하게 되어 피부입사선량도 증가된다. 또한 영상증배관의 확대지 수(magnification factor)가 높아질수록 $\mathrm{AK}$ 와 $\mathrm{DAP}$ 는 일 관되게 높아진다리영앙 확대를 하면 단위면적의 방 사선 수가 감소하고 이에 따라 영상의 밝기가 감소한 다. 이를 자동으로 보정하기 위해 더 높은 관전류를 동원하여 영상을 획득하게 된다. 즉 $\mathrm{FOV}$ 를 12 inch에 서 9 inch로 감소시키며 확대한다면, 상대입사선량은 약 2 배 증가하게 된담1ㄷ․ 본 연구에서도 $\mathrm{FOV}$ 에 의한 영상이 25 inch에서 15 inch로 확대되었을 때의 선량은 2 배 정도 증가되었기 때문에 심혈관 촬영 시 가급적이 면 영상을 확대하지 않는 것이 선량감소에 효과적이 다.

본 연구의 제한점은 선량 감소를 위한 기하학적 특 성 중 실무자가 조절 가능하다고 판단되는 요인만 확 인하였기 때문에 기기적 측면에서 선량 감소 방안이 충분히 더 있을 수 있을 것으로 생각된다. 또한 실험 장비가 1 대였기 때문에 본 연구의 선량감소율을 심혈 관장비 전체에 적용시키기에는 무리가 있다. 그럼에도 불구하고 실무자가 조절 가능한 기하학적 매개변수로 선량을 감소시킬 수 있음을 확인하였고, 장비의 특성 을 충분하게 숙지한 상태에서 검사가 진행될 경우 실 무자에게 많은 도움이 될 것으로 사료된다. 


\section{$\mathrm{V}$. 결 론}

심혈관검사 용 디지털 혈관 영화장치의 기하학적 특성에 따른 선량변화에 관한 연구 결과에서 기하학 적 특성인 FPS mode, X-선관 각도, 조사야 조절장치, $\mathrm{X}$-선관과 영상증배관 거리, 테이블과과 영상증배관 거 리, $\mathrm{FOV}$ 영상확대 등은 중재적 시술 시 실무자가 수 시로 조절 가능한 기하학적 특성이며, 각 특성에 따라 충분히 선량 감소 효과를 얻을 수 있다. FPS mode에 따른 선량은 FPS를 낮게 설정할수록 선량이 $70 \%$ 까지 감소하였다. 선관 각도에 따른 선량은 $\mathrm{LAO}$ $45^{\circ}+$ Caudal $30^{\circ}$ 이 가장 높게 측정되었고, 조사야 조절 장치를 많이 적용할수록 선량은 감소하였다. X-선관과 영상증배관의 거리가 $10 \mathrm{~cm}$ 멀어질수록 투시촬영과 영화촬영에서 각각 선량이 $25-35 \%$ 까지 증가하였다. $\mathrm{FOV}$ 가 확대될수록 선량이 1.21-2배 증가하였고, 테이 블과 영상증배관 거리가 $10 \mathrm{~cm}$ 멀어질수록 선량은 1.11-1.25배까지 증가하였다.

따라서 디지털 혈관 영화장치의 기하학적 특성에 따른 선량감소 효과를 올바르게 알고 심혈관 검사 시 적절히 이용한다면, 환자 및 검사자에 대한 선량 감소 에도 기여 할 것이다.

\section{참고문헌}

[1] J Persliden. Patient and staff doses in interventional X-ray procedures in Sweden, Radiation Protection Dosimetry. Vol. 114, No. 1, pp. 150-157, 2005.

[2] D Bor, T Sancak, T Olgar: Comparison of effective doses obtained from dose-area product and air kerma measurements in interventional radiology, The British journal of Radiology, Vol. 77, pp. 315-322, 2004.

[3] Vano E, Goicolea J, Galvan C, et al. Skin radiation injuries in patients following repeated coronary angioplasty procedures, The British Journal of Radiology, Vol. 74, No. 887, pp. 1023-1031, 2001.

[4] Wall BF, Hart D. Revised radiation dose for typical x-ray examinations. Report on a recent review of doses to patients from medical X-ray examinations in the UK by NRPB, The British Journal of Radiology, Vol. 70, No. 833, pp. 437-439, 1997.
[5] 정홍량, 임청환, 이만구: 전국 종합병원 방사선사의 개인피폭선량에 대한 고찰, 방사선기술과학, Vol. 28, No. 2, pp. 137-144, 2005.

[6] 윤철호, 윤석환, 최준구: 방사선 종사자 근무 분야별 피폭에 관한 검토, 방사선기술과학, Vol. 31, No. 3, pp. 217-222, 2008.

[7] International Commission on Radiological Protection, 2000b. Avoidance of radiation injuries from medical interventional procedures, ICRP Publication 85

[8] Interventional Atomic Energy Agency Radiation Protection of Patients. 10 Pearls: radiation protection of patients in fluoroscopy, Vienna IAEA, 2013.

[9] 식약청, 방사선 안전관리시리즈 No. 11: 중재적 시술 방사선 방어 가이드 라인, 2006.

[10] Vano E, Gonzalez L, Van Loon R, et al. Radiation exposure to medical staff in interventional and cardiac radiology. The British Journal of Radiology, Vol. 71, No. 849, pp. 954-960, 1998.

[11] National Radiological Protection Board. Estimation of effective dose in diagnostic radiology from entrance surface dose and dose-area product measurements, NRPB report, 262, 1994.

[12] Ayad M. Risk assessment of an ionizing-radiation energy in diagnostic radiology, Applied Energy, Vol. 65, No. 1, pp. 321-328, 2000.

[13] Gfirtner H, Stieve FE, Wild J: A new Diamentor for measuring kerma-area product and air-kerma simultaneously, Med Phys, Vol. 24, No. 12, pp. 1954-1959, 1997.

[14] J C Le Heron. Estimation of effective dose to the patient during medical X-ray examinations from measurements of the dose-area product, Phys Med. Biol. Vol. 37, No. 11, 1992.

[15] Mahadevappa Mahesh. The AAPM/RSNA Physics Tutorial for Residents, Fluoroscopy: Patient Radiation Exposure Issues, Radiographics, Vol. 21, Np. 4, pp. 1033-1045, 2001.

[16] 정우경. 투시와 중재시술의 방사선 피폭과 저감화 방법, J Korean Med Assoc, Vol. 54, No. 12, pp. 1269-1276, 2011. 